\title{
Analysis of a goat milk cheese industry in a desert rangeland of Mexico
}

\author{
Walter J Gómez-Ruiz, Juan M Pinos-Rodríguez , Juan R Aguirre-Rivera and Juan C García-López
}

\author{
* Correspondence: jpinos@uaslp.mx \\ Programa Multidisciplinario de \\ Posgrado de Ciencias Ambientales \\ e Instituto de Investigación de \\ Zonas Desérticas, Universidad \\ Autónoma de San Luis Potosí, San \\ Luis Potosí 78377, Mexico
}

\begin{abstract}
The study aimed to identify the goat milk value chain for the benefit of producers in a desert rangeland of Mexico. Using retrospective analysis, we characterized goat milk and cheese production and commercialization and profitability at the community and regional levels. What should be done for a cooperative with all stakeholders, using strategic management methodologies is determined. Goat husbandry had an explosive growth in the second third of last century, but disorganized growth deteriorated the rangelands and the activity is declining. Milk productivity has declined up to seven times in some regions compared with the 1960s. It is still the main source of earned income in the region but disorganization persists in all aspects from production to commercialization, and the common use of the rangelands. Producers are depleting their natural resources due to low incomes. Milking and cheese production are unhygienic, uncomfortable and too time consuming, while commercialization is informal. The vision and mission show a group that wants to succeed through profitable and sustainable commercialization. Milk production potential should be increased through better use of natural resources and optimization of the herd's general management. Organization for the use of the rangelands, standardized small-scale processing, commercialization and technology transfer is the hope for sustainable rural development in this region. The high fat content of the goat milk in the region should increase its price.
\end{abstract}

Keywords: Goat milk, Goat cheese, Commercialization, Strategic planning

\section{Background}

The main economic activity of the pastoral people of San Luis Potosi highlands (SLPH) is grazing animals (goats), complemented with rainfed agriculture and the gathering of diverse plant materials (Haenlein 1998). In many dry areas of Mexico, goat husbandry is the main economic activity. Most of the 9,000,000 goats in Mexico are managed as a family activity. It was calculated in 1991 that 320,000 families or rural units depend on goat husbandry as their main form of livelihood (INEGI, 2005). With a national average of 32 goats per rural unit, around 22,000 families in the SLPH depend on goat husbandry (INEGI, 2005). Poverty in Mexico is highly focalized in the rural areas with parts of this highlands included among the poorest. Moreover, goat husbandry as it is now practiced is unsustainable; its low economic returns, as the main problem, are leading to its demise (Hoyos and Salinas 1994; Hernández et al. 2001). From 1994 to 2004 the number of head in the main part of the SLPH decreased by $68 \%$ compared with a national reduction of $10 \%$, while in the world as a whole it increased by $21 \%$

(c) 2012 Gómez-Ruiz et al.; licensee Springer. This is an Open Access article distributed under the terms of the Creative Commons Attribution License (http://creativecommons.org/licenses/by/2.0), which permits unrestricted use, distribution, and reproduction in any medium, provided the original work is properly cited. 
(INEGI 2005). This is correlated with a decline in the size of the rural population and an increase in average age. The average farmer age in several areas is around 50 years since young men tend to out-migrate in search of better opportunities, and so women, children and old men take care of the goats (Figure 1). Several authors have argued for the need to sustain the rural population and reduce the rate of rural-urban migration (Haenlein 1998; Daza et al. 2004).

Unsound management of the natural resources in most common lands in Mexico has led to their general deterioration; this is one of the most serious environmental problems in Mexico and other parts of the world (Millennium Ecosystem Assessment 2005), and it has had a negative impact on goat husbandry (Figure 2). A World Resources (2005) highlights the importance of preserving the natural resources if the poor are to improve their livelihoods. Merino and Bray (2005), studying common lands, found that when good governance exists, those communities with an economic interest in their natural resources are more likely to try to preserve them and to use them sustainably. Thus, increasing the profitability of goat husbandry may provide an opportunity to keep the rural areas populated by improving the livelihoods of producers while motivating them to take better care of their resources. In achieving this, it is increasingly clearer that market aspects are vital (Albu and Griffith 2005). In particular, generating income, supporting milk enterprises and linking them to markets are effective tools in fighting poverty and improving livelihoods (Bennett et al. 2000).

Even though most of the income comes from goat husbandry and potentially mainly from its milk products, all aspects of their commercialization from the product's processing to its marketing are extremely rudimentary and highly disadvantageous for the producers. With the growing importance of market standards and expectations, the situation is expected to become worse. Because of the socio-economic importance of goat husbandry for the region, different efforts by the government and NGOs have been made, to help solve the situation, but never with a business-oriented methodology in a participatory manner that includes all stakeholders.

In an effort to understand the origin of the present situation, its tendencies and causes, the objectives of this study were 1) to review the background of goat husbandry focusing on the milk production part of the system in the San Luis Potosí highlands, 2) to characterize aspects of the milk value chain from production to commercialization so as to understand the present situation, and 3), using strategic

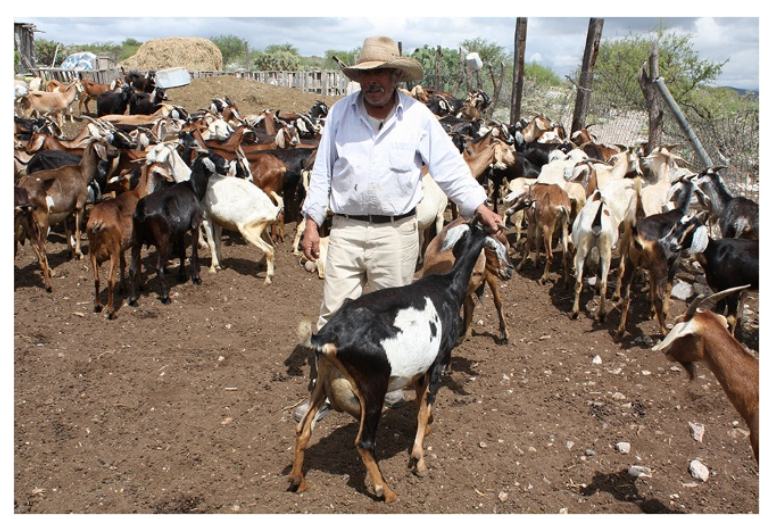

Figure 1 Old man taking care of a flock. 


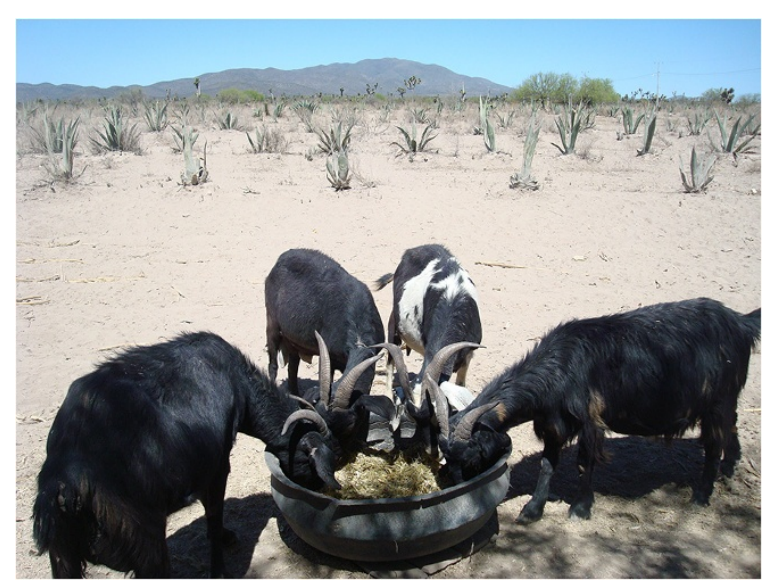

Figure 2 Goats supplemented with non-conventional feed as a result of the deterioration of natural resources in Mexican rangelands.

management methodologies normally used in business, to determine the steps required to help link the producers to markets and improve their livelihoods. The study aimed to find a solution at the regional or macro level, but in order to better understand the system, community-based research also took place at the micro level.

\section{The San Luis Potosi highlands}

The San Luis Potosi highlands are located in northwestern San Luis Potosi and comprise the southernmost part of the Chihuahuan Desert in Mexico. These highlands are a vast, uninterrupted sequence of elevated lands separated here and there by more or less isolated mountain ranges (Rzedowski 1961). They lie approximately between $24^{\circ}$ north and $22^{\circ}$ south latitude and between $102^{\circ}$ and $100^{\circ}$ west longitude. They encompass $21,510 \mathrm{~km}^{2}$ and the altitude ranges between 1,500 to $2,000 \mathrm{~m}$. Rainfall is concentrated in the summer months, and mean annual precipitation varies from 200 to $500 \mathrm{~mm}$; mean annual temperatures vary between $16^{\circ} \mathrm{C}$ to $18^{\circ} \mathrm{C}$ (INEGI 2005). The climate is classified as semiarid and the vegetation as desert scrub, with Creosotebush, Larrea tridentata, as the prominent element which often covers large expanses. Rosette succulents such as Agave lechuguilla, Dasylirion wheeleri, and Yucca spp., are predominant features. In general, most of the territory is used as rangeland with localized irrigated areas and some rainfed lands, normally located to make use of rainfall runoff. Ninety seven percent of the land is unfit for agriculture (INEGI 2005). Most of the 700,000 goats in the region are managed extensively, sometimes complemented with subsistence crop by-products.

\section{Community based study participatory work}

San José de la Peña $\left(23^{\circ} 15^{\prime} \mathrm{N}\right.$ and $\left.100^{\circ} 50^{\prime} \mathrm{W}\right)$, municipality of Villa de Guadalupe, was selected for its level of organization and willingness to participate in the investigation. It is representative of milk-oriented systems in the San Luis Potosi highlands and includes 11 households, averaging 56 goats per producer with a semi-extensive milkkid oriented system. The goats browse in the common rangelands, and their diet is complemented by milled maize and maize and beans straw from the summer, with oats 
as a winter forage crop. The households' only products for sale are goat kids, culled goats and fresh cheese, the cheese representing around 60\% of their annual income. Work at the community in general aims to research all aspects leading to better production and commercialization; currently, goat feeding, sanitary, and other management aspects are being studied, but this paper focuses on those aspects more directly involved in improving commercialization.

The structure of the study examines 1) What the situation of goat milk systems has been in the SLPH; based on review of the literature and interviews with key informants, 2) Present situation at the regional level: Interviews with intermediaries and retailers in markets, meetings and discussions with multi-stakeholders, and sampling cheese at markets, 3) Characterization of milk production, its conversion into cheese and its commercialization at the community and regional levels, including its profitability. This part was based on a review of literature and rapid rural appraisal, followed by regular household surveys and participatory workshops, implementation of a milk and cheese control program, and sampling milk and cheese for physical-chemical and microbiological analysis.

\section{Milk testing methods}

An EKOMILK analyzer for the physical-chemical analysis gave readings for density, \% protein, \% fat, and \% non-fat solids. The pour plate method was used for counting mesophilic aerobic bacteria and fecal and total coliforms. A potentiometer was used for $\mathrm{pH}$ and acidity was measured by titration following the AOAC guidelines. Data on quantities milked, lactation days and physical-chemical results for milk were used for correlations and for a hierarchical cluster analysis. An ANOVA was run for the $\mathrm{pH}$ and acidity data of fresh cheese found in the community and that of cheese sold in the market. Statistical analysis was run with SPSS 14 software.

\section{What should be done?}

To determine the strategies required to link producers to markets effectively, strategic management methodologies were used. Strategic management can be defined as the art and science of formulating, implementing and evaluating cross-functional decisions that enable an organization to achieve its objectives. Only the formulating part or strategy planning was done in the study, and the organization in this case is the cooperative of goat producers. The general objective was consensually decided by a multidisciplinary committee made up of the project's leaders, including researchers, agribusiness advisors and government officials, to guide the internal and external diagnoses and their analysis (SWOT analysis). The strengths (S) and weaknesses $(\mathrm{W})$ are attributes of the cooperative, and the opportunities $(\mathrm{O})$ and threats $(\mathrm{T})$ are attributes of the environment, and are the basis for the internal and external diagnoses. The internal and external diagnoses and the SWOT analysis (David 2003) were conducted by the multidisciplinary committee.

\section{History of the region's goat husbandry for milk production}

The goat was introduced to America by the Spanish probably in the mid-16th century (González 1977). The highland region was inhabited by groups of nomad 
Indians called Chichimecas who waged war against the colonisers from 1550 until the end of that century. With the Spaniards' victory over the native Americans, land distribution started. The first titles of land were granted in 1613 for raising livestock, including small ruminants. In 1616, Diego de Coronado founded livestock holdings in what is now Villa de Guadalupe (Morán 2001). Haciendas-vast expansions of private property-were founded for the commercial exploitation of natural resources in the early 17th century. By 1786 goat husbandry was the main source of wealth in at least one hacienda in the SLPH. Fat was the main product and was considered the best ingredient for manufacturing soap and candles for illumination, and the animal skins were used to make mezcal (an alcoholic beverage) containers. Fat for candles and lamp oil was progressively substituted by paraffin and seed oils, mainly cotton seed oil, but the skins found a market in the USA. Meat had a low value and was consumed by the workers on the haciendas (Bazant 1975), whose culture required that resources be used entirely; it is believed that they used the milk and produced rustic cheese for their own consumption at the haciendas.

There is evidence that goats prevailed in the arid and semi-arid zones during the 19th century (González 1977), and some haciendas raised large herds to export the hides, the third most exported product in Mexico by the end of the 19th century (González 1977). The practice of adding salt to the curd and storing the cheese in brine must have been started to expand the shelf life of the product and open the possibility of transporting cheese to distant markets. The salted product, after leaving it to air dry, becomes what in the region is known as Saltierra cheese, typical in all the goat-producing areas of the highlands.

San José de la Peña (SJP), the study site, was once part of the Zaragoza de Solís hacienda, which occupied two thirds of the present municipality of Villa de Guadalupe. According to the accounting books of the hacienda, goat husbandry was the main economic activity, with a herd of up to 30,000 head in the 19th century. The goats were skinned and the leather exported, while the meat was almost given away. To increase the size of the hides, the Creole (local) breed was crossed with Nubian, a practice that must have had an incidental impact on milk production. Milk was not commercialized because the markets were distant, but it was surely consumed and made into cheese in the hacienda.

After generations, the hacienda was subdivided among family members, who founded smaller haciendas and continued to raise goats for the skins. However, based on their own needs, in the 1930s they created a milk processing company: Coronado. The milk was mixed with sugar, evaporated and concentrated, reducing milk mass by more than 90\%, transforming it into a non-perishable condensed milk locally called paste. Easier to transport than milk, the paste was taken to the city of San Luis Potosi to finish the process of transformation into cajeta, a sweet soft caramel unique to Mexico, and with a large market.

The Mexican Revolution in the early 20th century partially interrupted goat husbandry in the region, and the hacienda lands were finally distributed among the workers in 1936. As the new holders of most of the land and rangelands, many ex-workers of the haciendas became independent goat keepers. With the growing number of producers, the Coronado Company installed milk concentrating plants in different points of the region. These had milk collection routes to buy milk and take it to the plant to be converted into paste. 
Goat herders pastured their herds extensively over the rangeland, and after the kids were born, they were weaned at one month of age to be sold to intermediaries who traveled from camp site to camp site. The does (adult female goats) were then hand milked (Figure 3) in the camp sites. From there, collectors would take the milk into the village by cart or motorcycle, charging $10 \%$ of the value of the milk for the service. They would load the milk and pay for it in cash. This activity peaked in the 1960s when San Jose produced 700 to $800 \mathrm{l} / \mathrm{d}$ a season. The collecting routes of the region yielded a minimum of 4,500 l/d in a bad year and around 8,000 l/d in a good one.

Flock sizes were considerable: today few producers have more than a hundred, while in the past flock-owners usually had between 200 and 1,500 head. In an effort to improve the milk part of the business, the Coronado Company introduced sires (adult male goats) of Nubian, Granadine and Alpine breeds. Apparently, the best results were obtained with Nubian, although some producers have good memories of the Granadine.

Regarding goats' milk productivity, González (1977) reported 1 l/d during the rainy season and $0.25 \mathrm{l} / \mathrm{d}$ during the dry season. For the Villa de Zaragoza region, average yield for Creole local breed animals is reported by retired producers as $0.5 \mathrm{l} / \mathrm{d}$, and reported to be $1 \mathrm{l} / \mathrm{d}$ for European sires (bucks) crossed with local breed does. These yields are high, considering that goat husbandry was practiced with extensive grazing, with little or no feed supplementation.

In the 1960s, competition for buying the milk started from other paste manufacturers and for the first time, from industrial cheese producers, consequently increasing the producer price of milk. Transportation systems developed, first with the advent of the railroad system to Monterrey, a city in northern Mexico and then a bus transportation route to Matehuala, the main city of the region, in the 1970s. This encouraged some producers to produce cheese on their own and take it themselves to the nearest city.

Since cheese in this region has been manufactured rustically, without pasteurization or adequate sanitary conditions, it has always been commercialized through informal channels. Middlemen networks have developed that exploit the producers' considerable commercializing difficulties and lack of a standardized product, and therefore middlemen can offer low prices.

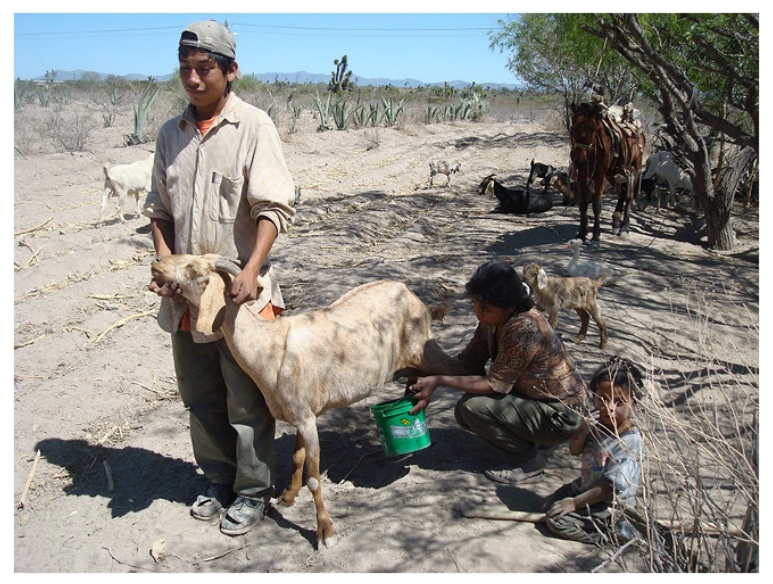

Figure 3 Goats are hand-milked in rural areas. 
Severe droughts in the 1970s, as well as political-economical problems in the country, forced many producers to sell their goat flocks and emigrate, so Coronado stopped operating regionally in the early 1980s. Since then the region has had a negative population growth rate. These factors, among others, together with goat husbandry's low economic return, have caused the number of goats to decline by $68 \%$ in the last ten years (INEGI 2005). Because of the reduction in goat numbers and the deterioration of the rangelands, the Villa de Guadalupe region today in a good year would yield 34\% of its milk yield in the 1960s.

\section{Development efforts on goat milk production}

In the 1970s, different actors (government, NGOs, and private groups) began a series of actions to develop the goat milk cheese industry as the best option to promote the region's rural development. None of the efforts prospered for different reasons. In the early 1970s a plant with an installed capacity of forty thousand litres a day was built with government aid in Villa de Hidalgo, another municipality in the San Luis Potosí highlands. It operated for four years but had to be abandoned because of bad administration and political reasons. Several small plants obtained by different producer organizations with government aid in different communities of the highlands have failed because of disputes among their associates. In the mid 1990s, Desarrollo Rural, an NGO, collected milk from communities and produced French-style goat cheese but failed for lack of quality control and marketing channels. The same NGO collected milk in the highland communities from 1994 to 1998 and successfully sold it to a candy company until a new administration arrived. After 2000, different private groups started cheese production and commercialization businesses with their own feed-lot flocks of goats, but failed because of problems in marketing.

\section{Present situation}

\section{Characterization of milk production}

The goats of today are a result of crosses between the Creole local breed and various other breeds that have been used in an effort to improve the local breed's productivity (Figure 4). Milk yield and composition vary due several factors, some of which are intrinsic to the animal, such as the breed mixture (Daza et al. 2004). Correlations performed on milk productivity and quality in San Jose de la Peña indicate that non-fat solids are positively correlated with fat $\%$ and protein $\%$, as well as with density, but the first three are all highly correlated negatively with average days of lactation.

Hierarchical cluster analysis identified two main groups of goats. Flocks with Boer and local breed crosses had low milk yield but the highest contents of non-fat solids, fat and protein. The other group is made up of producers who graze their Nubian breed in the mountains where the forage is available. These herds had a higher milk yield but lower solid content. Percentages of fat, protein, non-fat solids and density tended to be higher in the samples taken during the dry season than those taken during the rainy season. The average concentration of fat was $6.8 \%$. The former milk buyers in the region report fat contents of $6 \%$ or even $7 \%$; extension agents in other regions of the highlands also report fat contents of around $6 \%$. 


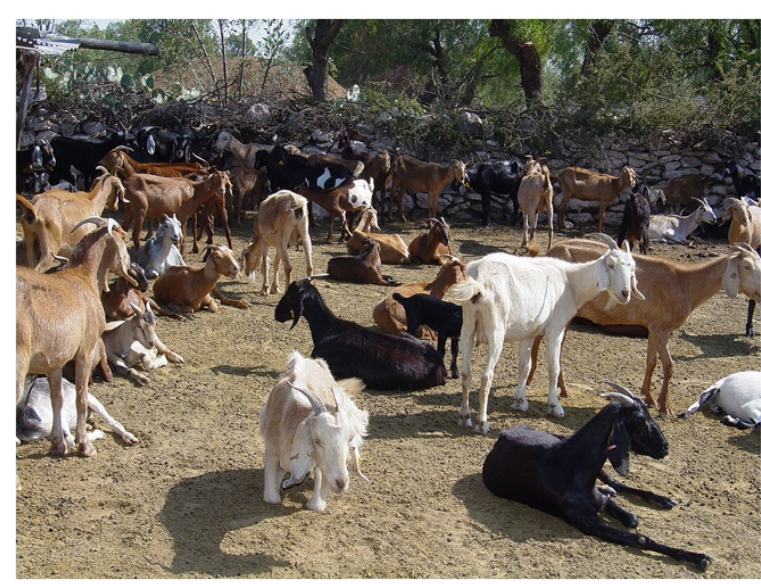

Figure 4 Different goat breeds used in the dry areas, including pure and crossbreeds.

The diversity of breeds has caused different problems: altered seasonality of the reproduction cycle from generation to generation in some cases and altered rusticity of the goats in others. Stakeholders in the project have thus agreed on the need to standardize the genetic potential of goats to match that of their environment.

Microbiological analyses were run to determine the sanitary conditions of the milking process. Mesophilic aerobic bacteria (MAB) total coliform (TCC) and fecal coliform count (FCC), were used as indicators. Total count varied greatly among the ten producers with results ranging from 2 to $7.4 \log \mathrm{ufc} / \mathrm{ml}$ for $\mathrm{MAB}$ and from 2 and $7.54 \log$ $\mathrm{ufc} / \mathrm{ml}$ for TCC; fecal coliform count averaged $3 \log \mathrm{ufc} / \mathrm{ml}$ for half the samples. The results evidence insufficient sanitary care in all cases.

\section{Milking}

Each goat is chased in the corral until caught. The producer then kneels down behind it and holds the goat's rear foot in between his knees and starts milking into a plastic bucket with one or both hands. The goats running around in the corral kick up dust and manure and part of this settles into the bucket. Conditions in general are unhygienic and uncomfortable for producers, who perceive as main constraints, from most to least important, lack of equipment, pain in their hands, management difficulties (open location, cleanness, chasing each goat, and others) and leg pain.

\section{Cheese production}

Milk is carried to the house and heated if required. Natural non-standardized rennin is added without measuring, and after the curds set, they are checked for cutting resilience with a spoon. If ready, they are cut with the spoon and stirred to promote whey separation. The curd is then pressed by hand in the pot. Women dip their hands carefully into the curd and with slow and gentle movements pack the solids together for 20 minutes They say the warmth of their hands helps separate the whey. Then they bring handfuls of solids out of the whey and start compacting it between their hands, above the pot so the whey drips back into it. As soon as they feel it is dry enough they place it into a mould, where they continue to press by hand to make it firmer and give it its final shape. Moulding takes seven to 10 minutes per cheese. Moulds are improvised, made of anything they can find that is round. Of the 10 women who produce cheese, only one had a simple mechanical press. Cheese pieces are approximately $600 \mathrm{~g}$ each. 
They are put into a salt water solution $(20 \%$ salt in the summer and $16.6 \%$ in the winter) where they are preserved and stored until sold. Preparing the rennin solution is a complex process that takes a week and requires a fresh suckling kid's stomach, which they sometimes buy at a market in the city. Constraints as perceived by the producers, in order of importance, are pressing and whey removal, quality and uniformity of rennin, milk temperature at arrival, cheese curdling, and cleanliness. The main quality control problems are variable strength of natural rennin, no exact measurements (amount of rennin, temperatures, $\mathrm{pH}$, and process times), and scarce sanitary conditions.

\section{Cheese characterization}

Fresh cheese made at the communities when purchased by middlemen may be conserved in brine for periods varying from three days to three months; it is then dried by exposure to the air, altering its salt content, texture, maturation and humidity. This drier product is known as Saltierra cheese. The fresh and Saltierra cheese types were found to be significantly different in $\mathrm{pH} 6.84$ and 5.94, and acidity 0.016 and 0.143 , respectively, indicating that Saltierra is a more aged cheese. Mesophilic aerobic bacterial and total coliform counts were also significantly lower for Saltierra cheese; this may be due to the extra salt added during preservation in brine for Saltierra cheese (Hutton 2002). Microbial counts in both cheeses, however, were far above the Mexican norm, and fresh cheese was also far above the limits of the Mexican norm for fecal coliforms. Fresh and Saltierra goat cheese in the region are products of doubtful food safety, variable consistency, odour and flavour, and occasionally, they are sour and have holes.

\section{Commercialization at the community and regional levels}

Most if not all of the milk produced by rural families in the region is sold fresh. Organized production efforts are few and almost all the families produce and commercialize their own cheese through informal market channels. Most sell to middlemen, especially in time of abundance during the rainy season, but nearby markets absorb most of the local production during the dry season when demand is higher than production. Middlemen take advantage of their difficulties, and the producers' need for money gives the middlemen strong bargaining power and thus producer prices are low.

Middlemen preserve the cheese in brine until they have enough for a three tone truckload. There are reports of up to three or four trucks per week going to San Luis Potosi in times of abundance when they buy cheap. They wash and preserve the product in cold rooms in the city to be sold more expensively in times of scarcity. Most is sold to retailers in the San Luis Potosi city markets who sell the drier Saltierra cheese. It is sold as a generic product with no wrapping, brand or specific shape, but it has gained good acceptance through the years among lower income segments of the population. The smallest producers use the same retailer or sell to contacts in times of scarcity. In some families one of the members sells cheese door-to-door in nearby communities.

\section{Profitability}

A two year study was conducted in the community of 11 producers, considering their present cheese production, their varying commercializing strategies through time (with the actual selling prices and costs of sale), and all their expenses of inputs acquired outside of their system, including purchased feedstuffs, veterinary products, salts, fuel, and agricultural inputs. These variable costs were allocated according to the percentage of 
income derived from the sale of goat dairy products. Results showed that producers lose 50 to $70 \%$ of their profits when they sell cheese to middlemen. Since the cost of family labour is not included because they do not pay for it, the profit margin is actually part of their own family salary. In addition, a marginal labour analysis shows that the extra work in manufacturing and selling cheese, compared with just selling the milk, on average, provides incomes almost twice their earnings per hour, considering their whole business. Thus, cheese-making is the most lucrative part of producers' business.

Middlemen average a gross margin of \$1.15 USD per kg over the average prices paid to producers and retailers sell with an average gross profit of \$ 0.92 USD per kg. Retail prices are still higher in selling points near the northern border or in the United States.

\section{Threats and opportunities for development of pastoralism of SLPH}

The main threat to goat husbandry was the tendency for the activity to disappear and the consequent rural depopulation. The external diagnosis indicated that the goat pastoralists have not used their opportunities enough.

Opportunities were basically support from government, research and development as well as access to other better markets based on organization of the pastoralists for normalized and standardized production and commercialization of goat milk products. The strengths of these pastoralists can be summarized in the fact that they are a group of dedicated goat producers in a suitable environment that has a potential for higher milk production if the system is optimized and their project is supported by a good demand for the product. Optimization of the system depends on the reduction of the weaknesses identified in the multi-stakeholder meeting. These weaknesses can be summarized as problems with all aspects of flock management, use of natural resources, and informal and unprofitable commercialization. The internal diagnosis resulted in a favourable balance between strengths and weaknesses for the pastoralist group.

\section{Conclusions}

Disorganized production and commercialization is leading to the disappearance of goat husbandry; most producers receive only a fraction of the retail price of their milk. Organization for the rational use of the natural resources, small-scale processing in compliance with norms and for commercialization is the hope for producers to increase their current returns sustainably. Aid in technology transfer is required.

It is necessary to develop milk production potential through better use of natural resources and optimization of general management of the animals, including genetic selection of goats to match their environment.

The high fat content is a characteristic of the region's goat's milk that should be exploited to raise consumer appreciation and price of the cheese.

Competing interests

The authors declare that they have no competing interests. 


\section{Acknowledgment}

This work was supported by: (i) CONACYT through a Doctoral Scholarship granted to WJGR; (ii) International Centre for Agricultural Research in Dry Areas (ICARDA) and (ii) International Fund for Agricultural Development (IFAD) Project: "Strengthening institutional capacity to improve marketing of small ruminant products and income generation in dry areas of Latin America.

Received: 16 February 2012 Accepted: 4 May 2012

Published: 17 May 2012

\section{References}

Albu, M., and A. Griffith. 2005. Mapping the Market: A framework for rural enterprise development policy and practice. Practical Action, 36. Warwickshire, UK: Markets and livelihoods program.

Assessment, M.E. 2005. Ecosystems and Human Well-being: Synthesis. Washington, DC, USA: Island Press. 155 p.

Bazant, J. 1975. Cinco haciendas mexicanas tres siglos de vida rural en San Luis Potosí. (1600-1910), 229. México D.F: El Colegio de México.

Bennett, A., J. Draaijer, B. Dugdill, J.-B. Lambert, T. Thapa, and FAO of the UN. Animal Production Service. 2000. Report on the FAO E-mail Conference on small-scale milk collection and processing in developing countries, 156. Rome, Italy: Animal Production and Health Division.

David, F. 2003. Conceptos de administración estratégica. 9a ed. Pearson. Naucalpan, Edo. de México, México.

Daza, A., C. Fernández, and A. Sánchez. 2004. Ganado caprino. Producción, alimentación y sanidad, 312. Madrid, España: Agrícola Española.

González, A. 1977. El Ganado caprino en México, 177. México, D.F: Instituto Mexicano de Recursos Naturales Renovables A.C.

Haenlein, G. 1998. The value of goats and sheep to sustain mountain farmers. Int J Anim Sci 13: 187-194.

Hernández, J., E. Rodero, M. Herrera, J.V. Delgado, C.Y. Barba, and A. Sierra. 2001. La caprinocultura en la mixteca poblana (México). Descripción e identificación de factores limitantes. Arch Zootec 50: 231-239.

Hoyos, G., and Y.H. Salinas. 1994. Comercialización de leche y carne de Caprinos en la Comarca Lagunera. México 44: 122-128.

Hutton, T. 2002. Sodium: Technological functions of salt in the manufacturing of food and drinks. British Food Journal 104(2): 126-152

INEGI. 2005. Anuario estadístico del estado de San Luis Potosí. Tomo II Instituto Nacional de Estadística Geografía e Informática, 816. Aguascalientes, México: Gobierno del estado de San Luis Potosí.

Merino, L., and D. Bray. 2005. La experiencia de las comunidades forestales en México:: Veinticinco años de silvicultura y construcción de empresas forestales comunitarias. http://ine.gob.mx/publicaciones/new.consultaPublicacion.php accessed January 30, 2007.

Morán, C. 2001. Matehuala. Orígenes y Fundación, 113. San Luis Potosí, México: Caracol de Oro-Conaculta.

Rzedowski, J. 1961. Vegetación del estado de San Luis Potosí. Tesis doctoral, 228. México, D.F.: Universidad Nacional Autónoma de México.

World Resources. 2005. The Wealth of the Poor. Managing Ecosystems to Fight Poverty. World Resources Institute (WRI) in collaboration with United Nations Development Program, 268. Washington, DC: WRI: United Nations Environment Program, and World Bank.

doi:10.1186/2041-7136-2-5

Cite this article as: Gómez-Ruiz et al: Analysis of a goat milk cheese industry in a desert rangeland of Mexico. Pastoralism: Research, Policy and Practice 2012 2:5.

\section{Submit your manuscript to a SpringerOpen ${ }^{\circ}$ journal and benefit from:}

- Convenient online submission

Rigorous peer review

- Immediate publication on acceptance

- Open access: articles freely available online

- High visibility within the field

Retaining the copyright to your article

Submit your next manuscript at $\gg$ springeropen.com 